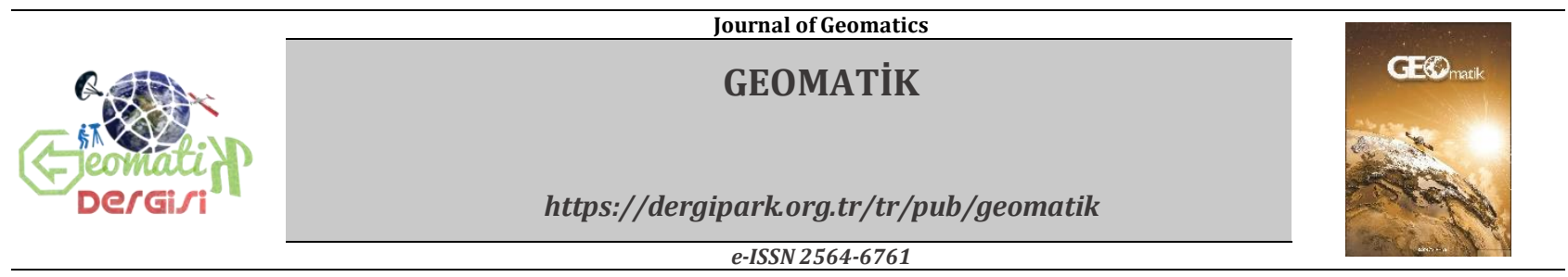

\title{
Artvin Örneğinde Arsa Vasıflı Taşınmaz Malların Değerini Etkileyen Faktörlerin Analizi
}

\author{
Ayşe Yavuz Özalp*, Halil Akıncı, Sebahat Temuçin Kılıçer
}

Artvin Çoruh Üniversitesi, Mühendislik Fakültesi, Harita Mühendisliği Bölümü, Artvin, Türkiye

\author{
Anahtar Kelimeler \\ Taşınmaz değerleme \\ Arsa vasıflı taşınmaz mal \\ Analitik hiyerarși prosesi \\ Taşınmaz değer indeksi
}

\begin{abstract}
ÖZ
Bu çalışmada, Artvin kent merkezinde arsa vasıflı taşınmaz malların fiziksel ve konumsal özellikleri ele alınarak değere etki eden faktörlerin ve etki derecelerinin Analitik Hiyerarşi Proses (AHP) yönteminden yararlanılarak belirlenmesi ve akabinde çalışma alanını oluşturan yedi mahalledeki 273 adet arsa vasıflı taşınmaz malların, taşınmaz değer indekslerinin tespiti amaçlanmıștır. Çalışmanın son adımında ise tespit edilen bu taşınmaz değer indekslerinin, taşınmazların üzerinde bulundukları cadde ve sokakların emlak rayiç değerleri ile analizi hedeflenmiștir. Çalıșmanın sonucunda, Artvin kent merkezinde arsa vasıflı taşınmaz mallar üzerinde 15 faktörün etkili olduğu ve bu faktörler içinde en çok etkiye sahip üçünün "şehir merkezine yakınlık", "sokak genişliği" ve "toplam inșaat alanı" iken, en az etkili faktörlerin "hastaneye yakınlı", "ilkokula yakınlık" ve "parselin konumu" olduğu tespit edilmiştir. Bunlara ilaveten, çalışmada incelenen arsa vasıflı taşınmaz malların değer indekslerinin 1.07 - 4.36 aralığında değiştiği ve en yüksek puanlı parsellerin genellikle Çarşı Mahallesi'nde yer aldığı ve alanca \%90'ından daha fazla kullanılabilir alana sahip olduğu ve tamamına yakınının emsalinin yüksek olduğu belirlenmiştir. Yine cadde/sokakların emlak rayiçlerinin düşük olduğu ve taşınmaz malın gerçek değerini yansıtmadı̆̆ı, aynı cadde/ sokak üzerinde emlak rayiç değerleri aynı olmasına rağmen parsellerin farklı değerlerde olduğu gözlenmiştir. Dolayısıyla taşınmaz malların parsel tabanlı gerçek değerlerinin belirlenmesi, kent bazlı değer indeks haritalarının üretilmesi ve ihtiyaç duyulduğu durumlarda parsel tabanlı gerçek değerlerin taşınmazla ilgili işlemlere (alım-satım, bankacılık, kamulaştırma gibi) servis edilmesi oldukça önemli ve elzemdir.
\end{abstract}

\section{Analysis of Parameters Affecting Value of Real Estates with Land Property in Artvin Case}

\section{Keywords}

Real estate valuation

Real estate with land property

Analytic Hierarchy Process

Real estate value index

\begin{abstract}
In this study, by using Analytic Hierarchy Process (AHP) method, it was aimed to determine the parameters affecting value of real estates with land property and their degrees of influence in respect to their physical and spatial features for seven neighborhoods in Artvin city and then to determine real estate value index of 273 land properties in seven neighborhoods that constitute the study area. In the last step of the study, it was targeted to analyze this determined real estate value index with land fair values of the streets they are found on. As a result of this study, it was found that 15 parameters were effective on real estates with land property in Artvin city center and that while the three most effective parameters among them were "proximity to the city center", "street width" and "total construction area", the least effective factors were "proximity to hospital", "proximity to primary school" and "location of the parcel". Besides, it was determined that the value indexes of real estates with land property examined varied between $1.07-4.36$ as the parcels with the highest points were generally located in Çarşı Neighborhood, having more than $90 \%$ usable area and almost all of them had high precedent. In addition, it was observed that the street based fair values were very low and did not reflect the real value of the real estates and the parcels had quite different values despite located on the same street having same prices per square meters. Therefore, it is very important and essential to determine the parcelbased real values of real estates, to produce city-based value maps and to serve these parcel-based real values to the real estate transactions (buying and selling, banking, expropriation etc. ) when needed.
\end{abstract}

*(ayavuzozalp@artvin.edu.tr) ORCID ID 0000-0002-8297-9034 (hakinci@artvin.edu.tr) ORCID ID 0000-0002-9957-1692 (stemucin@artvin.edu.tr) ORCID ID 0000-0001-5839-6616
ÖZALP, A , AKINCI, H , TEMUÇiN KILIÇER, S . (2020). Artvin Örn eğinde Arsa Vasıflı Taşınmaz Malların Değerini Etkileyen Faktörlerin Analizi. Geomatik , 5 (2) , 100-111. DOI: 10.29128/geomatik.579401 Retrieved from https://dergipark.org.tr/tr/pub/geomatik/issue/52495/579401 Geliş Tarihi: 18/06/2019; Kabul Tarihi: 01/08/2019 


\section{GíRiş}

Ülkelerin ekonomisinde önemli bir role sahip olan alım-satım, vergilendirme, kamulaştırma, kredilendirme, miras, sigortacılık gibi birçok işlemin gerçekleşmesi taşınmaz malların değerinin bilinmesini gerektirir (Yılmaz \& Demir, 2011; Yalpır, 2014; Emek \& Öztürk, 2015; Bozkurt, 2016). Bir taşınmaz malın değerini; taşınmaz malın jeolojik ve topoğrafik özellikleri, bölgedeki emlak piyasası, bulunduğu bölge içerisindeki konumu, imar koşulları, bulunduğu bölgenin demografik yapısındaki değişiklikler (bölgesel özellikleri) etkileyebileceği gibi, ticari ve sınai trendler, hükümetlerin mali politikaları, enflasyon, yüksek faiz, kredilendirme koşulları gibi ülkesel politikalar da etkilemektedir (Karaca, 2008). Taşınmaz değerini etkileyen faktörlerin çok sayıda olması, yöresel özelliklere göre çeşitlilik göstermesi ve değerlemede kullanılacak faktörlerin, mekana, zamana ve kişiye bağlı olarak değişebilmesi kesin bir taşınmaz değerleme modelinin oluşturulamamasına ve böylece taşınmaz malın değerinin kesin olarak belirlenememesine yol açmaktadır. Yine alıcıların öncül tercihleri değer üzerinde etkili olmakla birlikte bu tercihlerin modele dahil edilmesi olanaksızdır. Ancak değişik parametrelerin dikkate alınması ve fiziksel özelliklerin doğru analizi ile taşınmaz malın yaklaşık değerinin belirlenebilmesi de mümkündür (Yomralıoğlu, 1995; Bin, 2004; Bozkurt, 2016).

$\mathrm{Bu}$ kapsamda, mevcut taşınmaz değerleme sistemleri incelendiğinde, ülkemizde değerleme işlemlerinin; belirli bir yasal temeli olmayan, bilimsellikten ve nesnellikten uzak, öznel kararlara göre işleyen bir sistem olduğu, aynı taşınmaz mal için farklı kurum ve kuruluşlarca farklı değerlemelerin yapıldığı, hatta aynı kurum tarafından aynı taşınmaz için farklı değerlemelerin yapıldığı, uygulamada tespit edilen taşınmaz mal birim değerlerinin serbest piyasa koşullarındaki değerlerden önemli derecede farklılıklar gösterdiği görülmektedir. $\mathrm{Bu}$ durum, taşınmazlara ilişkin değerleme işlemlerinin yeniden ele alınarak bir düzene kavuşturulmasını gerekli ve kaçınılmaz kılmıştır. Nitekim son yıllarda ülkemizde, bilimsel ve kurumsal bağlamda çeşitli çalışmalar gerçekleştirilmekte ve taşınmaz değerleme süreci sağlıklı bir temele oturtulmaya çalışılmaktadır. $\mathrm{Bu}$ çalıșmalardan biri Tapu ve Kadastro Genel Müdürlügü'nün 2008 yılında Dünya Bankası desteği ile başlattığı Tapu Kadastro Modernizasyon Projesi (TKMP)'dir. Bu projenin dördüncü bileşeni "Taşınmaz Değerleme" konusuyla ilgilidir. Söz konusu projede, taşınmazın türüne (konut, arsa, arazi) göre değeri etkileyen parametrelerin belirlenmesi ve standartların oluşturulması çalışmaları gerçekleștirilerek 2011 yılında rapor yayınlanmıştır (TKMP, 2014). Yine bu kapsamda Ağustos 2018'de açıklanan 100 Günlük Eylem Planında "Taşınmaz Değerleme Sisteminin Kurulması" konusuna yer verilmiştir ve akabinde ilgili yönetmelik çalışmaları başlatılmıştır. Öte yandan, arsa niteliğindeki tașınmaz malların değerlemesiyle ilgili bazı çalışmalara bakıldığında, Deveci ve Yllmaz (2009)'un Afyonkarahisar'da yaptıkları çalışmada 19 parametre, Timur (2009)'un Şişli'de yaptıkları çalışmada 5 parametre, Çakır ve Sesli (2013)'ün Samsun'da yaptıkları çalışmada 15 parametre ve TKMP (2014)'ün Ankara'da yaptıkları çalıșmada 36 parametre kullandıkları gözlenmiștir. Dolayısıyla taşınmazın değerini etkileyen faktörlerin lokal özelliklere göre değişebileceği gerçeği de dikkate alındığında, bu çalışmaların ülke tamamına yayılması oldukça önem taşımaktadır.

$\mathrm{Bu}$ bağlamda, taşınmaz piyasasına ilişkin herhangi bir çalışma ve araştırmaya sahip olmayan zorlu topoğrafyasıly Artvin kenti dikkate alındığında bu çalışmaların gerçekleştirilerek literatüre kazandırılması oldukça anlamlı ve önemlidir. Dolayısıyla bu çalışmada, Artvin kent merkezinde (Balcıoğlu, Çamlık, Çarşı, Çayağzı, Dere, Orta ve Yenimahalle olmak üzere 7 mahalle ölçeğinde) lokal özellikler de dikkate alınarak arsa vasıflı taşınmaz malların değerini etkileyen faktörlerin ve etki derecelerinin belirlenmesi ve Taşınmaz Değer İndeksi Haritasının üretilmesi amaçlanmıştır. Bu amacı gerçekleştirirken Analitik Hiyerarşi Proses (AHP) yönteminden yararlanılmıştır.

\section{MATERYAL ve YÖNTEM}

\section{1. Çalışma Alanı}

Çalışma alanı olarak, Artvin kent merkezinin onaylı İmar Planı sınırı içinde kalan 7 mahalle (Balcıoğlu, Çamlık, Çarşı, Çayağzı, Dere, Orta ve Yenimahalle) seçilmiştir. Söz konusu çalışma alanı,

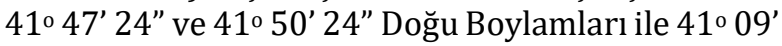

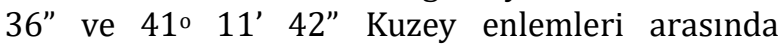
konumlanmış 768.91 ha büyüklüğünde bir alandır (Șekil 1). Kentin güney batısında, 182.90 ha yüzölçümü ile Kafkasör Kent Ormanı bulunmaktadır. Yamaca kurulu bir yerleşim alanı olan Artvin kent merkezinde yükseklik, $180 \mathrm{~m}$ ile $1280 \mathrm{~m}$ arasında değişmektedir (Yavuz Özalp vd. 2013).

Oldukça engebeli ve dağlık yapısı ile dikkat çeken Artvin kent merkezinde heyelan duyarlılığı da önem arz etmektedir. Bu kapsamda Akıncı vd. (2015) tarafindan yapılan çalışmaya göre, Artvin kent merkezinin \% 40'ı ve mevcut imar planındaki yapı adalarının \% 68'i yüksek ve çok yüksek derecede heyelan duyarlılığına haizdir.

$\mathrm{Bu}$ bağlamda çalışma alanının coğrafi konumu ve zorlu topoğrafyası, kent merkezinde yerleşime uygun alanları oldukça kısıtlamaktadır. Söz konusu bu kısıtlılık, son yıllarda yapılan barajlar nedeniyle yerleşim alanlarının sular altında kalması da eklendiğinde, Artvin kent merkezindeki taşınmaz pazarında önemli hareketlenmelere yol açmıştır. Gelinen noktada kent merkezi dikkate alındığında 2015 yılında 71 adet, 2016 yılında 50 adet ve 2017 yılında 69 adet "ana taşınmaz satıșı" (Bağımsız 
Bölüm hariç) gerçekleşirken, bağımsız bölüm bazında ise 2015 yılında 154, 2016 yılında 230 ve 2017 yılında 230 adet konut satışa konu olmuştur (TKGM, 2019). Bu çalışmada, 2015 yılında satışa konu olan arsa vasıflı taşınmaz mallardan, çalışma kapsamında üretilen Taşınmaz Değer İndekslerinin analizi sürecinde yararlanılmıștır.

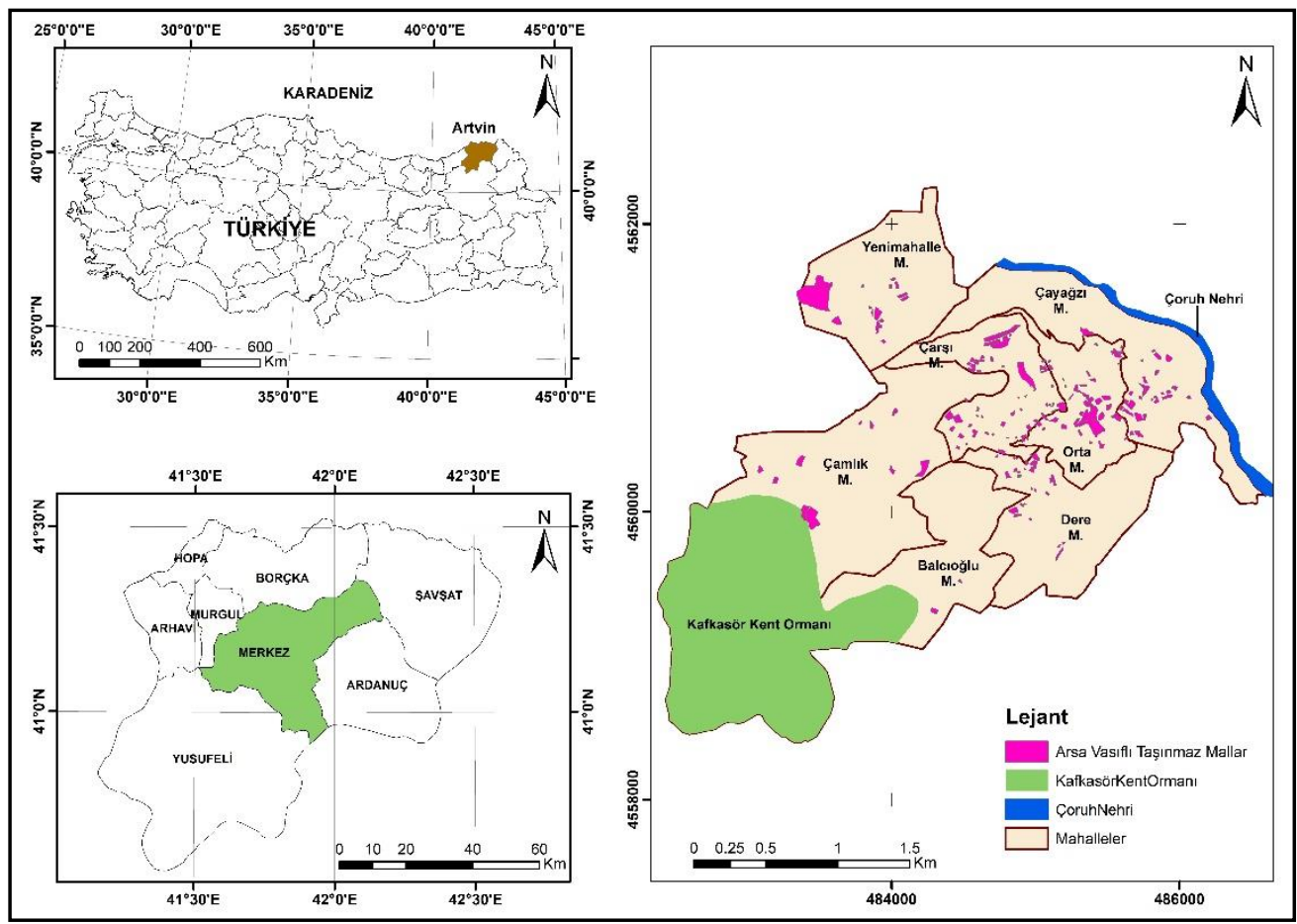

Şekil 1. Çalışma alanının konumu

\subsection{Arsa Vasıflı Taşınmaz Malların Değerini Etkileyen Faktörlerin Belirlenmesi}

Değerleme çalışmalarında, yapılan işlemin doğruluğu ve tutarlılığı, modelin doğru oluşturulmasına, bu ise değere etki eden faktörlerin ve etkilerinin doğru biçimde belirlenmesine bağlıdır. $\mathrm{Bu}$ nedenle taşınmaz malın değerini etkileyen faktörlerin seçilmesinin ve etki düzeylerinin belirlenmesinin, taşınmaz değerleme sürecinin en önemli ve zorlu adımı olduğu söylenebilir (Çakır \& Sesli, 2013; Yavuz Özalp \& Akıncı, 2017a). Aynı zamanda, taşınmaz malın değerini etkileyen parametrelerin taşınmazın türüne (arsa, arazi, konut, işyeri gibi) ve konumlandığı coğrafyanın özelliklerine göre değişiklikler göstereceği de kabul edilen bir gerçektir. Bu nedenle hem teorik anlamda hem de uygulama boyutunda taşınmazların değerini belirlemeye yönelik çok sayıda çalışmalar gerçekleştirilmiştir. Ancak ülkemiz ölçeğinde taşınmazın değerini etkileyen faktörler ve ağırlıkları hususunda standartlar henüz oluşturulamamıştır.

$\mathrm{Bu}$ bağlamda kurumsal bazda yapılan Tapu Kadastro Modernizasyon Projesi (TKMP) oldukça önem taşımaktadır. Proje kapsamında taşınmazın değeri üzerinde etkiye sahip olabilecek yaklaşık 80 parametre listelenmiş ve Ankara/Mamak ile İstanbul/Fatih ilçelerinde 2 pilot uygulama gerçekleştirilmiştir. Mamak ilçesinde arsa vasıflı taşınmaz mallar için yapılan uygulamada 36 parametre (TKMP, 2014) kullanılmıştır. Benzer şekilde literatürde birçok çalışmada da (Yomralığlu, 1995; Deveci \& Yllmaz, 2009; Karakayacı \& Karakayacı, 2012; Çakır \& Sesli, 2013; Akış, 2013; Yalpır \& Ünel, 2016; İlhan, 2017) arsanın değeri üzerinde etkili olabilecek çeşitli faktörler listelenmiștir. Bunlar; arsanın konumu ve biçimi, toprağın fiziksel yapısı, yola cephe uzunluğu ve yolun genişliği, imar yollarının mevcutta açık olup olmaması, imar planiyla getirilen kısitlamalar (kat sınırlaması, arsanın kullanılma oranı gibi), parselin köşe sayısı, parselin dar ve uzun bir yapıda olması, parselin kullanım alanı vb. şeklinde sıralanabilir. Görüldüğü gibi değeri etkileyen faktörlerin sayısı, bölge şartlarına bağlı olmakla birlikte kişiden kişiye de değişebilmektedir.

$\mathrm{Bu}$ çalışmada, Artvin kent merkezinin coğrafi koşulları ve fiziki özellikleri ile kentte emlak işiyle ilgilenen kişilerin (bilirkişiler, müteahhitler, emlakçlar ve konut/ gayrimenkul değerleme uzmanları) görüşleri doğrultusunda arsa vasıflı taşınmaz malların değerini etkileyen 15 faktör belirlenmiştir (Tablo 1). Bu kapsamda, taşınmaz değeri üzerinde etkiye sahip olduğu düşünülen sosyo-ekonomik faktörler (nüfus, rant, arz ve talep gibi) dikkate alınmamış sadece konumsal ve fiziksel özellikler ele alınmıştır. 
Tablo 1. Artvin merkezde arsa vasıflı tașınmaz malların değerini etkileyen faktörler

\begin{tabular}{llllll}
\hline F1 & Parselin konumu & F6 & Yapı nizamı & F11 & İlkokula yakınlık \\
F2 & Kat adedi & F7 & İmar planına göre kullanılabilir alan & F12 & Toplu taşımaya yakıınlık \\
F3 & Sokak genişliği & F8 & Cephe uzunluğu & F13 & Hastaneye yakınlık \\
F4 & Parselin alanı & F9 & Parselin ortalama eğimi & F14 & Kamu binalarına yakınlık \\
F5 & Toplam inşaat alanı & F10 & Şehir merkezine yakıılık & F15 & Bakı \\
\hline
\end{tabular}

\subsection{Verilerin Temini ve Hazırlanması}

Arsa vasıflı taşınmaz malların değeri üzerinde etkiye sahip faktörler belirlendikten sonra bu faktörlere ait verilerin temini ve arsa vasıflı taşınmaz malların (parsellerin) tespiti işlemi gerçekleștirilmiştir. $\mathrm{Bu}$ bağlamda çalışmanın materyalini olușturan arsa vasıflı parsellerin belirlenmesi amaciyla Artvin Kadastro Müdürlüğü'nden, çalışma alanını (7 mahalleye ait) kapsayan 1/1000 ölçekli sayısal formattaki Kadastro Altlıkları ve Parsel Öznitelik listesi temin edilmiștir. Temin edilen bu listeden faydalanarak vasfi "arsa" olan yapısız parseller belirlenmiş ve tüm konumsal ve konumsal olmayan veriler (taşınmazların mahallesi, vasfi, ada/parsel no, yüzölçümü gibi) ArcGIS 10.2 ortamında oluşturulan "Arsa Değer Veritabanı" na aktarılmıştır. Arsa vasıflı taşınmaz mallar belirlenirken, belediye imar planı sınırı içinde bulunan arazilerin arsa niteliği taşıdığı kabulü dikkate alınmıștır.

Ardından, arsa vasıflı tașınmaz malların değerinin belirlenmesinde etkili olacak faktörlere (sosyal donatılara, eğitim tesislerine, sağlık tesislerine olan uzaklık, topoğrafik durumu gibi) ait bilgiler 1/1000 ölçekli sayısal formattaki halihazır haritalardan yararlanarak elde edilmiștir. Ayrıca Artvin Belediyesi'nden raster formatında temin edilen 1/1000 ölçekli İmar Paftaları sayısallaștırılarak 7 mahalle bazında yapılașmaya tahsis edilen adalar ve özellikleri ile diğer kullanım alanları (eğitim, ticaret, rekreasyon gibi) belirlenerek veri tabanına eklenmiştir. Kadastro parselleri ile imar paftaları (özellikle yapı adaları) çakıştırılarak parsellerin yapılaşmaya uygun kısımları, yol genişlikleri, kat sayıları, TAKS, KAKS gibi bilgileri veritabanına aktarılarak değerlemede kullanılacak faktörlerin oluşturulması gerçekleștirilmiştir.

Çalışmanın bir sonraki adımında ise, Artvin Tapu Müdürlüğü'nden 2015 yllına ait (1 Ocak 2015 31 Aralık 2015 tarihleri arasında) alım-satıma konu olmuş arsa vasıflı taşınmaz malların listesi ve detay bilgileri (Ada/parsel no, yüzölçümü, vasfı, satış tarihi, satış bedeli gibi) temin edilerek oluşturulan veritabanına girilmiştir. Ayrıca söz konusu bu arsa vasıflı taşınmaz malların emlak vergisi beyan değerleri ve çalışma alanında yer alan cadde ve sokakların arsa birim fiyatları da Belediyeden temin edilerek veritabanına aktarılmıştır.

\subsection{Analitik Hiyerarşi Prosesi (AHP) Yöntemi}

Çok kriterli karar verme analiz yaklaşımlarından biri olan Analitik Hiyerarşi Proses (AHP) yöntemi taşınmaz değerleme uygulamalarında yaygın kullanılan yöntemlerden biridir. AHP, karar verme işlemini, amaca yönelik bir hiyerarşi şeklinde ele alan ve amaca hizmet eden kriterlerin, amaca ne kadar etki ettiğini karşılıklı karar matrisleri ile belirlemeyi sağlayan bir metottur. Dolayısıyla, değer tespit sürecinde birçok nesnel kriteri birlikte değerlendirmeyi gerektiren taşınmaz değerleme çalışmaları için uygun bir yöntem olduğu ve taşınmaz araştırmalarında yaygın biçimde kullanıldığı (Yılmaz \& Demir, 2011; Yalpır, 2014; Yavuz Özalp \& Akıncı, 2017a) söylenebilir. AHP yönteminde Saaty (1980) tarafından önerilen tercih ölçeğinden yararlanılarak bir puanlama yapılır ve ikili karşıllaştırma matrisi oluşturulur.

Ağırlıkların, başka bir ifadeyle önceliklerin belirlenmesi, ikili karșılaștırma matrisinin normalize edilmesi ile gerçekleștirilmektedir. Bu işlemde, matrisin sütun elemanları her bir sütun toplamına bölünerek "normalleştirilmiş ikili karşılaştırma matrisi" elde edilir. Elde edilen matristeki satır elemanları toplanır ve toplam değer, satırdaki eleman sayısına bölünerek öncelik vektörü ya da ağırlık vektörü elde edilir (Kavas, 2009; Akıncı vd., 2012). Ağırlıklar 0-1 aralığında değer alır ve toplamları 1'e eşit olur (Öztürk \& Batuk, 2010). İkili karşılaştırma yargılarının tutarlılığını ölçmek için Saaty (1980) tarafından önerilen tutarlılık oranı (Consistency Ratio - CR) hesaplanır. Saaty (1980)'e göre bu oran $0.10^{\prime}$ un altında olmalıdır. Yargılar için hesaplanan tutarlılık oranı 0.10 'un altında ise yargıların yeterli bir tutarlılık sergilediği ve değerlendirmenin devam edebileceği kabul edilmektedir. Eğer tutarlılık oranı 0.10'un üstünde ise yargılar tutarsız kabul edilmektedir. Bu durumda yargıların kalitesinin iyileștirilmesi gerekir. Tutarlılık oranı yargıların yeniden gözden geçirilmesiyle düşürülebilir (Akıncı vd., 2012).

\subsection{Değeri Etkileyen Faktörlerin Ağırlıklarının AHP Yöntemi ile Belirlenmesi}

Değeri etkileyen faktörlerin ağırlıklarının belirlenmesi, değerleme çalışmalarının en zor aşamalarından biridir. Her kent için taşınmaz değerlerinin belirlenmesinde esas alınan faktörler ve ağırlıklarının farklı olacağı bilinen bir gerçektir. Bu 
nedenle kent bazında değere etki eden faktörlerin ve etki seviyelerinin belirlenmesi daha anlaml olacaktır. Faktörlerin taşınmazın değerine olan etki düzeyini (ağırlığını) belirlemede AHP yöntemi kullanılmıștır. Kauko (2002)'nin de belirttiği gibi bölgeyi tanıyan değerleme uzmanlarının görüşlerinin alınması oldukça önemli olduğundan bu çalışmada, Artvin kent merkezinde bu işle uğraşan (2 Bilirkişi, 2 Müteahhit, 2 Emlakçı ve 1 Taşınmaz Değerleme Uzmanı) dolayısıyla Artvin taşınmaz pazarını derinlemesine analiz etmiş olan 7 kişilik değerleme uzman grubundan yararlanılmıștır. Söz konusu uzman grubuna faktörlerin birbirlerine göre önemlerini belirlemek üzere, ikili karşılaştırmalar yapılarak 9 birimlik ölçeğe göre (Saaty, 1980) faktörler puanlandırılmıştır. Faktörlerin ikili karşılaştırma matrisi ve hesaplanan ağırlıkları Tablo 2'de sunulmuștur.

Ardından ikili karșılaștırmaların tutarlılı̆̆ analiz edilmiștir. Çalıșmada kullanılan 15 faktör için tutarlılık oranı (CR) 0.0859 olarak bulunmuştur. Hesaplanan tutarlılık oranı değerinin 0.10'dan küçük olması (Saaty, 1980) karşılaştırmaların tutarlı ve kabul edilebilir hassasiyette olduğunu göstermektedir. Aynı uzman grubuna danışılarak alt parametreler de beşli ölçek bağlamında puanlandırılmıştır (Tablo 3). Böylece Artvin lokal koşulları dikkate alındığında hem arsa vasıflı tașınmaz malların değerini etkileyen faktörlerin ağırlıkları hem de bu faktörlerin alt parametre puanları belirlenmiștir.

Tablo 2. Faktörlerin ikili karşılaştırma matrisi

\begin{tabular}{|c|c|c|c|c|c|c|c|c|c|c|c|c|c|c|c|c|}
\hline Faktörler & $\vec{I}$ & $\stackrel{N}{ }$ & $m$ & 式 & 노 & ర) & 闰 & $\infty$ & 오 & 울 & 곺 & $\stackrel{\sim}{\vec{I}}$ & $\stackrel{m}{\vec{I}}$ & $\stackrel{\vec{I}}{E}$ & 늠 & $\begin{array}{l}\text { Ağırlık } \\
\left(w_{i}\right)\end{array}$ \\
\hline F1 & 1 & $1 / 4$ & $1 / 8$ & $1 / 6$ & $1 / 7$ & $1 / 5$ & $1 / 7$ & $1 / 6$ & $1 / 4$ & $1 / 9$ & 2 & $1 / 3$ & 3 & $1 / 2$ & $1 / 5$ & 0.0148 \\
\hline F2 & 4 & 1 & $1 / 6$ & $1 / 4$ & $1 / 5$ & $1 / 2$ & $1 / 5$ & $1 / 3$ & 1 & $1 / 7$ & 5 & 2 & 3 & 3 & $1 / 2$ & 0.0335 \\
\hline F3 & 8 & 6 & 1 & 3 & 2 & 4 & 2 & 3 & 5 & $1 / 2$ & 9 & 4 & 9 & 5 & 4 & 0.1483 \\
\hline $\mathrm{F} 4$ & 6 & 4 & $1 / 3$ & 1 & $1 / 2$ & 3 & $1 / 2$ & 2 & 5 & $1 / 4$ & 7 & 5 & 8 & 5 & 2 & 0.0893 \\
\hline F5 & 7 & 5 & $1 / 2$ & 2 & 1 & 3 & 1 & 3 & 5 & $1 / 3$ & 8 & 4 & 9 & 6 & 3 & 0.1142 \\
\hline F6 & 5 & 2 & $1 / 4$ & $1 / 3$ & $1 / 3$ & 1 & $1 / 4$ & $1 / 2$ & 2 & $1 / 7$ & 5 & 3 & 6 & 5 & 1 & 0.0507 \\
\hline F7 & 7 & 5 & $1 / 2$ & 2 & 1 & 4 & 1 & 2 & 4 & $1 / 3$ & 8 & 4 & 9 & 7 & 3 & 0.1126 \\
\hline F8 & 6 & 3 & $1 / 3$ & $1 / 2$ & $1 / 3$ & 2 & $1 / 2$ & 1 & 2 & $1 / 6$ & 5 & 4 & 6 & 4 & 2 & 0.0648 \\
\hline F9 & 4 & 1 & $1 / 5$ & $1 / 5$ & $1 / 5$ & $1 / 2$ & $1 / 4$ & $1 / 2$ & 1 & $1 / 6$ & 4 & 2 & 5 & 3 & $1 / 2$ & 0.0357 \\
\hline F10 & 9 & 7 & 2 & 4 & 3 & 7 & 3 & 6 & 6 & 1 & 9 & 5 & 9 & 6 & 4 & 0.2106 \\
\hline F11 & $1 / 2$ & $1 / 5$ & $1 / 9$ & $1 / 7$ & $1 / 8$ & $1 / 5$ & $1 / 8$ & $1 / 5$ & $1 / 4$ & $1 / 9$ & 1 & $1 / 5$ & 2 & $1 / 2$ & $1 / 6$ & 0.0118 \\
\hline F12 & 3 & $1 / 2$ & $1 / 4$ & $1 / 5$ & $1 / 4$ & $1 / 3$ & $1 / 4$ & $1 / 4$ & $1 / 2$ & $1 / 5$ & 5 & 1 & 5 & 2 & $1 / 3$ & 0.0303 \\
\hline F13 & $1 / 3$ & $1 / 3$ & $1 / 9$ & $1 / 8$ & $1 / 9$ & $1 / 6$ & $1 / 9$ & $1 / 6$ & $1 / 5$ & $1 / 9$ & $1 / 2$ & $1 / 5$ & 1 & $1 / 4$ & $1 / 6$ & 0.0098 \\
\hline F14 & 2 & $1 / 3$ & $1 / 5$ & $1 / 5$ & $1 / 6$ & $1 / 5$ & $1 / 7$ & $1 / 4$ & $1 / 3$ & $1 / 6$ & 2 & $1 / 2$ & 4 & 1 & $1 / 4$ & 0.0202 \\
\hline F15 & 5 & 2 & $1 / 4$ & $1 / 2$ & $1 / 3$ & 1 & $1 / 3$ & $1 / 2$ & 2 & $1 / 4$ & 6 & 3 & 6 & 4 & 1 & 0.0534 \\
\hline & & & & & & $=15$ & & & & & & & & 1.59 & & \\
\hline
\end{tabular}


Tablo 3. Alt faktörler ve puanları

\begin{tabular}{|c|c|c|c|c|c|c|c|c|}
\hline Faktörler & Alt-faktör & Puan & Faktörler & Alt-faktör & Puan & Faktörler & Alt-faktör & Puan \\
\hline Parselin & Köșe & 5 & \multirow{3}{*}{ Yapı nizamı } & Ayrık & 3 & \multirow{5}{*}{$\begin{array}{c}\text { Şehir } \\
\text { merkezine } \\
\text { yakınlık (m) }\end{array}$} & $0-250$ & 5 \\
\hline Konumu & Ara & 2 & & Bitişik & 5 & & $250-500$ & 4 \\
\hline \multirow{4}{*}{ Kat adedi } & 2 & 2 & & Blok & 3 & & $500-750$ & 3 \\
\hline & 3 & 3 & \multirow{5}{*}{$\begin{array}{l}\text { İmar planına } \\
\text { göre } \\
\text { kullanılabilir } \\
\text { alan }\end{array}$} & Tamamı & 5 & & $750-1000$ & 2 \\
\hline & 4 & 4 & & \%80-\%99 & 4 & & $>1000$ & 1 \\
\hline & 5 & 5 & & $\% 60-\% 79$ & 3 & \multirow{4}{*}{$\begin{array}{c}\text { İlkokula } \\
\text { yakınlı (m) }\end{array}$} & $0-150$ & 5 \\
\hline \multirow{3}{*}{$\begin{array}{c}\text { Sokak } \\
\text { genișliği } \\
(\mathrm{m})\end{array}$} & $<7$ & 2 & & \%40-\%59 & 2 & & $150-300$ & 4 \\
\hline & $7-10$ & 3 & & $<\% 40$ & 1 & & $300-450$ & 3 \\
\hline & $>10$ & 5 & \multirow{4}{*}{$\begin{array}{l}\text { Cephe } \\
\text { uzunluğu } \\
\text { (m) }\end{array}$} & $<8$ & 2 & & $>450$ & 1 \\
\hline \multirow{5}{*}{$\begin{array}{l}\text { Parselin } \\
\text { alanı } \\
\left(\mathrm{m}^{2}\right)\end{array}$} & $<150$ & 1 & & $8-12$ & 3 & \multirow{5}{*}{$\begin{array}{c}\text { Toplu } \\
\text { taşımaya } \\
\text { yakınlık (m) }\end{array}$} & $0-50$ & 5 \\
\hline & $150-300$ & 2 & & $12-18$ & 4 & & $50-100$ & 4 \\
\hline & $300-500$ & 3 & & $>18$ & 5 & & 100- 200 & 3 \\
\hline & $500-1000$ & 4 & \multirow{4}{*}{$\begin{array}{l}\text { Parselin } \\
\text { ortalama } \\
\text { eğimi }\end{array}$} & $<\% 15$ & 5 & & 200- 300 & 2 \\
\hline & $>1000$ & 5 & & $\% 15-\% 30$ & 4 & & $>300$ & 1 \\
\hline \multirow{7}{*}{$\begin{array}{c}\text { Toplam } \\
\text { inşaat } \\
\text { alanı }\end{array}$} & Emsal 1.2 & 5 & & $\% 30-\% 50$ & 2 & \multirow{4}{*}{$\begin{array}{c}\text { Kamu } \\
\text { binalarına } \\
\text { yakınlı (m) }\end{array}$} & $0-250$ & 5 \\
\hline & Emsal 0.9 & 4 & & $>\% 50$ & 1 & & $250-500$ & 4 \\
\hline & Emsal 0.3 & 2 & \multirow{5}{*}{$\begin{array}{c}\text { Hastaneye } \\
\text { yakınlı (m) }\end{array}$} & $0-500$ & 5 & & $500-1000$ & 3 \\
\hline & \multirow[t]{4}{*}{ Serbest } & 3 & & $500-1000$ & 4 & & $>1000$ & 1 \\
\hline & & & & $\begin{array}{c}1000- \\
2000\end{array}$ & 3 & Bakı & & 5 \\
\hline & & & & $>2000$ & 1 & & D,B, Düz & 3 \\
\hline & & & & & & & K, KD, KB & 1 \\
\hline
\end{tabular}

\subsection{Arsa Vasıflı Taşınmaz Malların Belirlenmesi}

Temin edilen kadastral altlıklardan faydalanarak vasfı "arsa" olarak kayıtlı 532 parsel belirlenmiştir. Burada hedef, yapısız parsellerin değerlerini tespit etmek olduğundan arsa niteliğindeki parseller seçilmiştir. Çalışmanın kentsel alanda gerçekleștiriliyor olması ve elbette ki Artvin ilinin topoğrafik yapısı azımsanmayacak sayıda alanca küçük parsellerin oluşmasına yol açmıştır. Çalışma alanında $0.57 \mathrm{~m}^{2}, 1 \mathrm{~m}^{2}, 2 \mathrm{~m}^{2}$ büyüklüklerinde parsellerin olduğu ve parsel alanlarının $0.57 \mathrm{~m}^{2}$ ile $29971.03 \mathrm{~m}^{2}$ arasında değiștiği gözlenmiștir. Yüzölçümüne göre parsel dağılımı Tablo 4'de görülmektedir. Bu tabloya göre 147 parsel $100 \mathrm{~m}^{2}$ nin altında ve 69 parsel 1 dönümün $\left(1000 \mathrm{~m}^{2}\right)$ üzerinde alana sahiptir.

Bu bağlamda toplam 13 parselin üzerinde kamu binaları (Hastane, ilköğretim okulları, Karayolları, DSİ, Özel idare gibi) bulunmaktadır. Yine tapuda arsa/bahçe vasfinda olmasına rağmen, yapılan kontrollerde çok katlı binaların söz konusu parsellerin üzerinde yer aldığ belirlenmiștir. Dolayısıyla üzerinde yapı olan parseller (kamu binaları da dahil), belli büyüklüğün $\left(100 \mathrm{~m}^{2}\right)$ altındaki parseller ve yapılaşma harici alanlara (eğitim tesisleri, yeşil alan, jeolojik sakıncalı alan, idari alanlar, orman vb.) konu olan parseller çalıșma kapsamı dışında tutularak toplam 273 parsel bu çalışmada ele alınmıştır.
Tablo 4. Yüzölçümü büyüklüklerine göre parsel dağılımı

\begin{tabular}{ll}
\hline Parsel Alanı $\left(\mathrm{m}^{2}\right)$ & Parsel Sayısı \\
\hline$<50$ & 78 \\
$50-100$ & 69 \\
$100-300$ & 154 \\
$300-500$ & 96 \\
$500-1000$ & 66 \\
$1000-2000$ & 37 \\
$>2000$ & 32 \\
Toplam & 532 \\
\hline
\end{tabular}

Çalışmada ayrıca Artvin kent merkezinde 2015 yllında satışa konu olan 584 taşınmazdan 47 tanesinin arsa nitelikli olduğu tespit edilmiştir. Söz konusu bu parsellerin tapuda gösterilen satış fiyatları ve emlak vergisi beyan değerleri temin edilerek üretilen taşınmaz değer indekslerinin analizinde yararlanılmıştır. Ancak Artvin kentinin fiziki şartları nedeniyle bu sayının oldukça az olduğu görülmektedir. Sayının az olmasında müteahhitlerin genelde arsaları kat karşıllı̆ı edinmeleri ve bu sözleşmeleri tapuya yansıtmamalarının da etkili olduğu söylenebilir.

\subsection{Arsa Vasıflı Taşınmaz Malların Değer İndekslerinin Belirlenmesi}

Artvin ili koşulları dikkate alınarak belirlenen 15 ana faktörün ağırlıkları (wi) (Tablo 2) ve alt faktörlerin puanları (Tablo 3) kullanılarak Artvin kent merkezindeki arsa vasıflı taşınmaz malların değer indeksleri belirlenmiştir. $\mathrm{Bu}$ doğrultuda üretilen model altta formüle edilmiştir. 


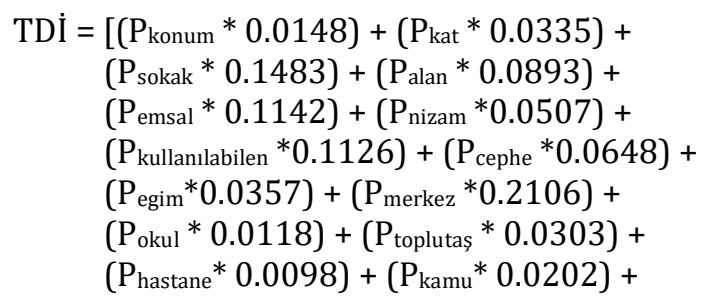

$\left.\left(\mathrm{P}_{\text {bakı }} * 0.0534\right)\right]$

Ardından (1) numaralı formül, seçilen 273 adet arsa vasıflı taşınmaz mala uygulanarak her birinin taşınmaz değer indeksi (TDİ) belirlenmiş (Tablo 5) ve haritada gösterilmiştir (Şekil 2).

Tablo 5. Arsa vasıflı tașınmaz malların değer indekslerine ait bir örnek

\begin{tabular}{cccccccccccccccccccc}
\hline Mahalle & Alan & Kullan_alan & F10 & F11 & F13 & F14 & F9 & F15 & F12 & F2 & F1 & F8 & F5 & F6 & F3 & F4 & F7 & TDI \\
\hline Çamlık & 381.57 & 0.00 & 1 & 1 & 3 & 2 & 3 & 1 & 1 & 0 & 0 & 5 & 0 & 0 & 0 & 3 & 0 & 1.07 \\
Çamllk & 1043.58 & 651.14 & 2 & 1 & 4 & 2 & 3 & 5 & 4 & 3 & 2 & 5 & 3 & 3 & 5 & 5 & 3 & 3.48 \\
Çamllk & 2612.86 & 0.00 & 1 & 1 & 3 & 2 & 3 & 3 & 1 & 0 & 0 & 5 & 0 & 0 & 5 & 5 & 0 & 2.10 \\
Çamllk & 175.01 & 173.54 & 2 & 2 & 4 & 4 & 3 & 1 & 4 & 2 & 5 & 5 & 2 & 3 & 2 & 2 & 4 & 2.62 \\
Çamlık & 816.76 & 816.76 & 2 & 2 & 4 & 5 & 3 & 3 & 4 & 2 & 5 & 5 & 2 & 3 & 2 & 4 & 5 & 3.04 \\
Orta & 941.49 & 860.21 & 4 & 2 & 4 & 5 & 1 & 1 & 3 & 4 & 5 & 5 & 3 & 3 & 3 & 4 & 4 & 3.47 \\
Orta & 4597.88 & 1910.87 & 4 & 2 & 4 & 5 & 1 & 5 & 2 & 4 & 5 & 5 & 3 & 3 & 5 & 5 & 2 & 3.81 \\
Orta & 7367.23 & 5193.93 & 4 & 2 & 4 & 5 & 3 & 1 & 2 & 4 & 5 & 5 & 5 & 3 & 5 & 5 & 3 & 4.01 \\
Orta & 72.27 & 72.27 & 3 & 2 & 4 & 5 & 3 & 3 & 5 & 4 & 2 & 5 & 3 & 3 & 3 & 1 & 5 & 3.29 \\
Orta & 724.09 & 705.86 & 5 & 5 & 5 & 5 & 3 & 5 & 4 & 5 & 2 & 5 & 3 & 3 & 5 & 4 & 4 & 4.32 \\
Orta & 1020.04 & 636.09 & 4 & 2 & 4 & 5 & 3 & 3 & 3 & 4 & 2 & 5 & 3 & 3 & 5 & 5 & 3 & 3.87 \\
Dere & 564.56 & 324.70 & 4 & 2 & 4 & 5 & 3 & 1 & 5 & 4 & 5 & 5 & 3 & 3 & 5 & 4 & 2 & 3.67 \\
Dere & 442.23 & 336.98 & 3 & 1 & 4 & 5 & 4 & 3 & 5 & 3 & 2 & 3 & 3 & 3 & 5 & 3 & 3 & 3.40 \\
Dere & 537.71 & 285.70 & 4 & 2 & 4 & 5 & 3 & 1 & 5 & 4 & 5 & 4 & 3 & 3 & 5 & 4 & 2 & 3.60 \\
Çayağzl & 1127.86 & 665.78 & 2 & 4 & 4 & 5 & 1 & 3 & 5 & 4 & 5 & 5 & 3 & 3 & 3 & 5 & 2 & 3.10 \\
Çayağzl & 2798.94 & 0.00 & 3 & 1 & 4 & 5 & 1 & 1 & 3 & 0 & 0 & 0 & 0 & 0 & 0 & 5 & 0 & 1.41 \\
Çayağzl & 553.61 & 411.24 & 1 & 5 & 3 & 5 & 1 & 1 & 4 & 3 & 2 & 5 & 3 & 3 & 3 & 4 & 3 & 2.70 \\
Balcığlu & 1391.65 & 0.00 & 1 & 1 & 3 & 2 & 3 & 3 & 1 & 0 & 0 & 0 & 0 & 0 & 5 & 5 & 0 & 1.78 \\
Çarșı & 748.46 & 729.84 & 5 & 2 & 5 & 5 & 3 & 5 & 5 & 5 & 5 & 5 & 3 & 3 & 5 & 4 & 4 & 4.36 \\
\hline
\end{tabular}

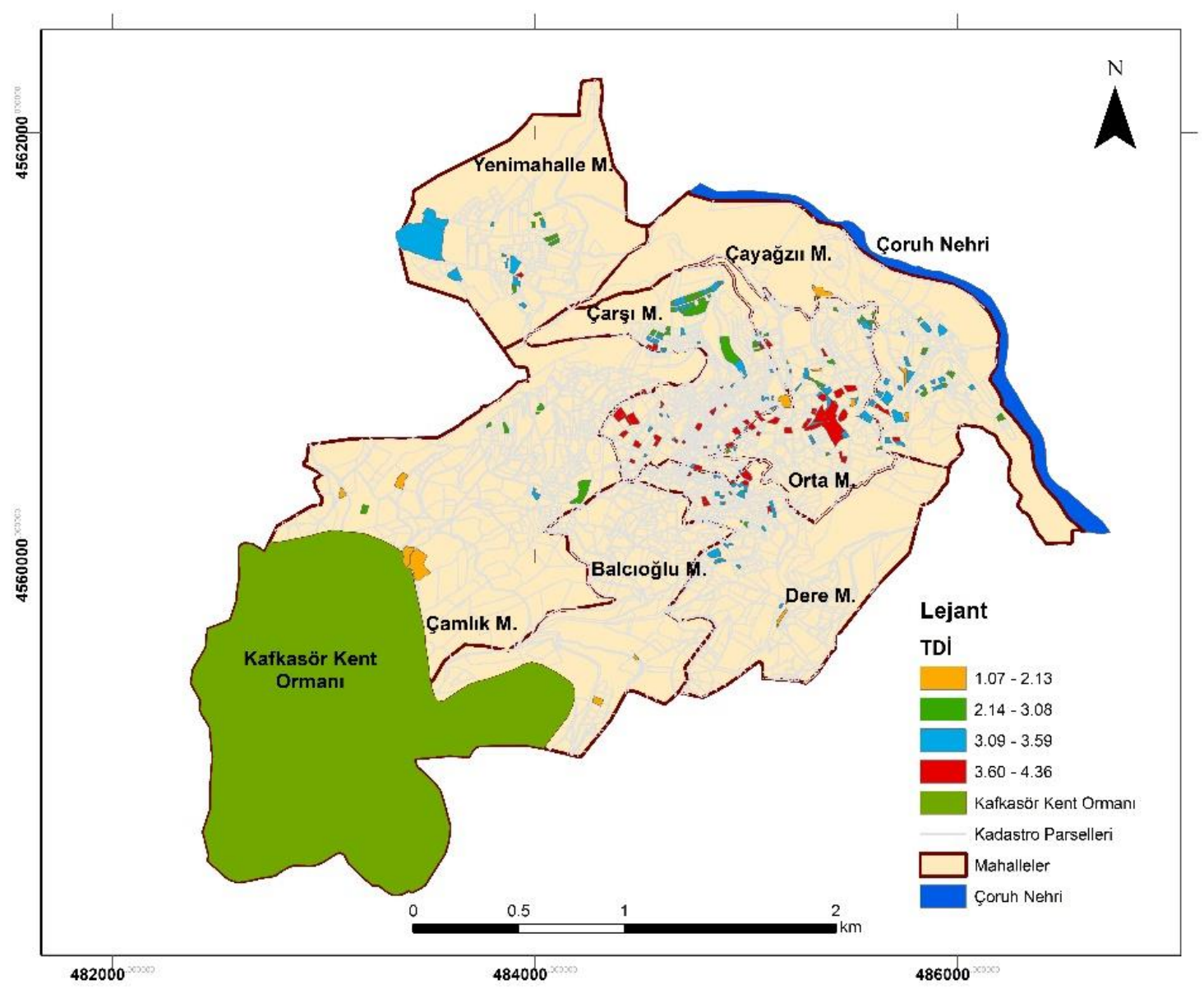

Şekil 2. Artvin kent merkezi arsa vasıflı taşınmaz malların değer indeksi haritası 


\section{BULGULAR}

\subsection{Arsa Vasıflı Taşınmaz Malların Değerini Etkileyen Faktörlerin ve Ağırlıklarının Analizi}

Bu çalışmada, AHP yöntemi kullanılarak uzman grubu görüşleri doğrultusunda 15 faktörün ağırlıkları (öncelikleri) belirlenmiştir (Tablo 2). Tablo 2 incelendiğinde, arsa vasıflı taşınmaz malların değeri üzerinde en etkili faktörün "Şehir merkezine yakınlık (w: 0.2106)" olduğu, bunu sırasıyla "sokak genişliği (w: 0.1483)", "toplam inşaat alanı (w: 0.1142)", "imar planına göre kullanılabilir alan (w: 0.1126)" ve " parsel alanı (w: 0.0893)" faktörlerinin takip ettiği görülmektedir. Bu bağlamda Timur (2009) da şehir merkezine olan uzaklık ile taşınmaz değerleri arasında negatif bir ilişkinin olduğunu ve kent merkezinden uzaklaştıkça taşınmaz değerlerinin düştüğünü belirtmiştir. Yine literatürdeki birçok çalışmada (Yusof \& Ismail, 2012; Ayan \& Erkin, 2014; Daşkıran, 2015) şehir merkezine yakınlık en önemli faktör olarak gösterilmiştir. Benzer şekilde Çakır ve Sesli (2013), Samsun'da yaptıkları çalışmada en etkili 2 faktörü, izin verilen kat adedi ve imar planına göre kullanılan alan olarak belirlemişlerdir. Yine Toktaş ve Erdoğan (2012) Afyonkarahisar'da yaptıkları çalışmada parselin imar durumunu en etkili parametre olarak bulmuşlardır.

Öte yandan arsa vasıflı taşınmaz malların değeri üzerinde en az etkili faktörün "hastaneye yakınlık (w: 0.0098)" olduğu tespit edilmiştir. Bunu sırasıyla "ilkokula yakınlık (w: 0.0118)" ve "parselin konumu (w: 0.0148)" faktörleri takip etmiştir. Bu parametrelerin arsa vasıflı taşınmaz malların değeri üzerinde en az etkili olmasında, Artvin'in küçük bir kent olması ve mesafelerin kolayca ulaşılabilir olması söylenebilir. Bununla birlikte Yavuz Özalp ve Akıncl (2017b)'nın Artvin'de konutlara yönelik yaptığı çalışmada, beklentilerin aksine, ilkokula yakınlığın fiyat üzerinde olumsuz bir etkiye sahip olduğu bulunmuştur.

Artvin kent merkezinin coğrafi yapısı ve zorlu topoğrafyası özellikle yapılaşma bağlamında oldukça fazla kısıtlar sunmaktadır. Bilindiği gibi arsanın düz ya da eğimli olması konut tasarımını ve yerleşme düzenini etkilemektedir. Eğim artıkça yerleşim, dolaşım ve bina yapımında bir takım sorunlarla karşılaşılabilir (Yetkin, 2009). Bu noktada \% 0-30 eğimdeki arazi yerleșime uygun kabul edilmektedir. Ancak kentsel alanların büyük bir kısmı (Artvin örneğinde de olduğu gibi) \%50'den fazla eğime sahip alanlarda planlanmıştır (Türk \& Erkan, 2018). Eğimin fazla olması yüksek istinat duvarlarının yapılmasına ve inşaat masrafının artmasına sebep olmaktadır. Yine yüksek eğim, yolların inşası sırasında çok fazla yarma ve dolgudan kaçınmak amacıyla enkesitlerin dar tutulmasına böylece dar yolların planlanmasına (7m, $10 \mathrm{~m}$ gibi) yol açmıştır (Türk \& Erkan, 2018). Uygulamada, eğimi az olan arsa ve arazilerin, eğimi fazla olanlara nazaran daha değerli olduğu kabul edilir. Nitekim bu çalışmada da "parselin ortalama eğimi (w: 0.0357)" ile ilgili elde edilen sonuç bu görüşü destekler niteliktedir.

Yine konut alanlarında yer seçimi yapılırken, güneş enerjisinden maksimum düzeyde yararlanabilmek oldukça önemlidir. Bu nedenle arsa seçiminde güneye eğimi olan araziler tercih edilir (Yetkin, 2009). İmar planıyla getirilen toplam inşaat alanı, kullanılabilir alan, yapı düzeni, kat adedi gibi koşullar, taşınmazın değeri üzerinde etki eden en önemli özelliklerdir (Utkucu, 2007). Bu noktada yeterli büyüklüğe sahip olmayan taşınmazların komşu parseller ile hukuksal ilişkiye zorlanması parselin değerini negatif yönde etkileyebilmektedir (İlhan, 2017). Bu çalışmada faktörlerin arsa vasıflı taşınmaz malların değeri üzerindeki etkilerine dair elde edilen sonuçlar beklentilerle uyumlu olmuştur.

\subsection{Arsa Vasıflı Taşınmaz Malların Değer İndekslerinin Analizi}

AHP yöntemi kullanılarak, Artvin kent merkezi örneğinde arsa vasıflı taşınmaz malların değerini etkileyen faktörlerin ağırlıkları belirlenmiş ve akabinde bu verilerden yararlanarak kent merkezindeki arsa vasıflı taşınmaz malların (273 parsel) taşınmaz değer indeksleri hesaplanmıştır. Söz konusu hesaplamaların neticesinde parsellerin değer indekslerinin 1.07 ile 4.36 arasında değiştiği görülmüştür. Bu bağlamda çalışmada ele alınan arsa vasıflı taşınmaz malların puan aralıklarına göre dağılımları Tablo 6'da sunulmuştur.

En düşük değer indeksli parseller ele alındığında, bunların çoğunlukla yol, yeşil alan gibi yapılaşmaya müsait olmayan alanlara denk geldiği başka bir ifadeyle kullanılabilir alanlarının oldukça düşük olduğu belirlenmiştir. Yine bu gruptaki parsellerden sadece 1 tanesi Çarşı Mahallesi'nde bulunmakta ve diğerleri kentin çeperlerinde, daha ziyade yapılaşmaya müsait olmayan alanlarda bulunmaktadır. $\mathrm{Bu}$ sonuç beklentiyle paralel doğrultudadır.

Tablo 6. Arsa vasıflı taşınmaz malların taşınmaz değer indeksine göre dağılımı

\begin{tabular}{lll}
\hline No & Puan Aralı̆̆ & Parsel Sayısı \\
\hline 1 & $1.07-2.13$ & 15 \\
2 & $2.14-3.08$ & 81 \\
3 & $3.09-3.59$ & 112 \\
4 & $3.60-4.36$ & 65 \\
\hline
\end{tabular}

En yüksek değer indeksli grupta yer alan 65 parsel incelendiğinde, 21 tanesinin Çarşı Mahallesinde yer aldığı, alanca $102 \mathrm{~m}^{2}$ ile $7367 \mathrm{~m}^{2}$ arasında olduğu, 47 parselin (yani \% 72) alanca \%90'ından daha fazla kullanılabilir alana sahip olduğu ve tamamına yakınının emsalinin yüksek olduğu tespit edilmiștir. 
Çalışmada ayrıca 2015 yllında satışa konu olan ve tapudaki satıș fiyatları mevcut olan 47 adet arsa vasıflı tașınmaz mal incelenmiștir (Tablo 7). Bu bağlamda arsa vasıflı taşınmaz malların metrekare satış fiyatlarının 0.36 TL ile 507.71 TL arasında değiştiği, 15 tanesinin metrekare fiyatının 10 TL'nin altında, 4 tanesinin ise $400 \mathrm{TL}$ üzerinde olduğu görülmüștür. Bu kapsamda mevcut veri setine göre yapılan hesaplamalarda tapudaki kayıtlı satış fiyatları ile tahmini fiyatlar arasında büyük farklılıklar tespit edilmiştir. Bu farklılıkların her iki yönde de mevcut olduğu başka bir ifadeyle bir yanda arsa vasıflı taşınmaz malların gerçek değeri altında satışı söz konusu iken öte yanda gerçek ederinden daha pahalıya satıldığı da gözlenmiştir. Bu rakamlar, literatürde de (Yahși, 2007; Kırar, 2008; Türkay, 2015) belirtildiği gibi ülkemizdeki tașınmaz mal satışlarının, Tapu Müdürlüklerinde, olduğundan daha az ya da daha fazla bir bedelle kaydedildiği gerçeğini de doğrulamaktadır. Ne yazık ki taşınmaz malların gerçek satş fiyatları kaydedilmemektedir ve bu değerlere erișim oldukça güçtür. Bu durum ise üretilen modellerin gerçeği ne oranda yansıttığının tespiti ve modellerin test edilmesini zorlaştırmaktadır (Tablo 7).

Tablo 7. Arsa vasıflı taşınmaz malların 2015 yılı tapudaki satış ve tahmini değerlerine örnek

\begin{tabular}{cccccccc}
\hline No & $\begin{array}{c}\text { Tapudaki } \\
\text { Satıs D. }\end{array}$ & $\begin{array}{c}\text { Tahmini } \\
\text { Değer }\end{array}$ & Oran (\%) & No & $\begin{array}{c}\text { Tapudaki } \\
\text { Satıș D. }\end{array}$ & $\begin{array}{c}\text { Tahmini } \\
\text { Değer }\end{array}$ & Oran (\%) \\
\hline 1 & 32000 & 42965,13 & 134 & 11 & 80000 & 117785,1 & 147 \\
2 & 11000 & 31854,89 & 290 & 12 & 60000 & 93970,3 & 157 \\
3 & 7500 & 103204,6 & 1376 & 13 & 73000 & 100620,4 & 138 \\
4 & 38273 & 80723,36 & 211 & 14 & 122699 & 114762,4 & 94 \\
5 & 2000 & 62287,29 & 3114 & 15 & 700 & 108725,7 & 15532 \\
6 & 38064 & 114661,6 & 301 & 16 & 600 & 79985,43 & 13331 \\
7 & 110000 & 128089,3 & 116 & 17 & 217210 & 118949,8 & 55 \\
8 & 900 & 97565,05 & 10841 & 18 & 99000 & 82803,75 & 84 \\
9 & 2750 & 88724,86 & 3226 & 19 & 567800 & 109570,3 & 19 \\
10 & 102000 & 116250 & 114 & 20 & 5495 & 77211,58 & 1405 \\
\hline
\end{tabular}

Bununla birlikte taşınmaz malların değerini etkileyen faktörlerin ve ağırlıklarının dikkate alınarak taşınmaz değer indeksinin belirlenmiş olması, bu değer indekslerinin güvenilir ve gerçekçi bir veri setinden yararlanılarak istenilen zaman için taşınmazın piyasa değeri hakkında bilgi vermesi açısından oldukça önem taşımaktadır.

Çalışmanın bir diğer aşamasında ise satışa konu olan arsa vasıflı taşınmaz malların emlak beyan değerleri incelenmiștir (Tablo 8). Bilindiği gibi taşınmaz malların satışında satış değerinin emlak beyan değeri (emlak vergisi değeri) altına düşmemesi yasal bir zorunluluktur. Buna rağmen fiyatlar incelendiğinde bu kuralın ihlal edildiği zaten düşük olan emlak beyan değerlerinin bile altında satışların gerçekleștiği gözlenmiştir. Dolayısıyla alım-satım işlemleri nedeniyle Devlet tarafından toplanan harç ve vergilerde ciddi bir kayıp söz konusudur. Ayrıca, Döner ve Alkan (2011)'in de belirttiği gibi bir taşınmaz mal için piyasa rayicinin altında veya çok üzerinde bir değer belirlenmesi gerek tapu ve belediyelerde vergi usulsüzlüklerine, gerekse bankalarda karşıllğı olmayan kredilerin verilmesine sebep olabilmektedir.

Tablo 8. Bazı arsa vasıflı taşınmaz malların tapudaki satış, emlak vergisi ve tahmini değerleri (TL)

\begin{tabular}{llllllll}
\hline No & $\begin{array}{l}\text { Tapudaki } \\
\text { Satıș D. }\end{array}$ & $\begin{array}{lllll}\text { Emlak } \\
\text { Vergisi D. }\end{array}$ & $\begin{array}{l}\text { Tahmini } \\
\text { Değer }\end{array}$ & No & $\begin{array}{l}\text { Tapudaki } \\
\text { Satıș D. }\end{array}$ & $\begin{array}{l}\text { Emlak } \\
\text { Vergisi D. }\end{array}$ & $\begin{array}{l}\text { Tahmini } \\
\text { Değer }\end{array}$ \\
\hline 1 & 32000 & 266289 & 42965,13 & 7 & 900 & 1322 & 97565,05 \\
2 & 7500 & 4936 & 103204,6 & 8 & 2750 & 833084 & 88724,86 \\
3 & 38273 & 75889 & 80723,36 & 9 & 100 & 107263 & 86751,15 \\
4 & 354600 & 23260 & 83743,18 & 10 & 60000 & 44712 & 93970,3 \\
5 & 1350 & 72135 & 97615,42 & 11 & 210000 & 99207 & 39734,89 \\
6 & 125730 & 73945 & 88392,95 & 12 & 48100 & 90579 & 86774,87 \\
\hline
\end{tabular}

Çalışmanın son adımında ise Artvin kent merkezindeki sokak ve caddelerin 2015 yllı emlak rayiç değerleri temin edilerek incelenmiştir. Kent merkezinde cadde/sokak rayiç değerlerinin $136 \mathrm{TL}$ ile $2416 \mathrm{TL}$ arasında değiştiği ve özellikle Çarşı Mahallesindeki Cadde ve sokakların daha değerli 
olduğu gözlenmiştir. Cadde/sokakların rayiç değerleri ile taşınmaz değer indeksleri çakıştırılarak incelenmiștir (Şekil 3). Şekil 3'e bakıldığında aynı cadde/ sokak üzerinde $\mathrm{m}^{2}$ fiyatı ayn olmasına rağmen parsellerin farklı değerlerde olduğu görülmektedir. Yine en değerli bazı parsellerin rayiç değeri en düșük sokak üzerinde yer aldığı ve belirlenen taşınmaz değer indeksi ile sokak rayiç değeri arasında makul bir ilişkinin olmadığ gözlenmiştir. $\mathrm{Bu}$ bağlamda, Yalpır vd. (2013) Konya'da yaptıkları bir çalışmada tapudaki satış değeri ile emlak vergisi değeri arasında çok farkın olmadığını, tapudaki satış değerinin, emlak vergisi değerine çok az ekleme yapılarak belirlendiğini, bununla birlikte piyasa değeri ile emlak vergisi değeri arasında büyük farkın olduğunu belirtmişlerdir. Ayrıca Belediyelerin belirlediği emlak vergisi değerlerinin çok düşük olduğunu ve taşınmaz malın gerçek değerini yansıtmadığını dolayısıyla taşınmaz malların gerçek değerlerinin belirlenmesinin ve fiyata yansıtılmasının ülke ekonomisi açısından büyük önem taşıdığını da ifade etmişlerdir.

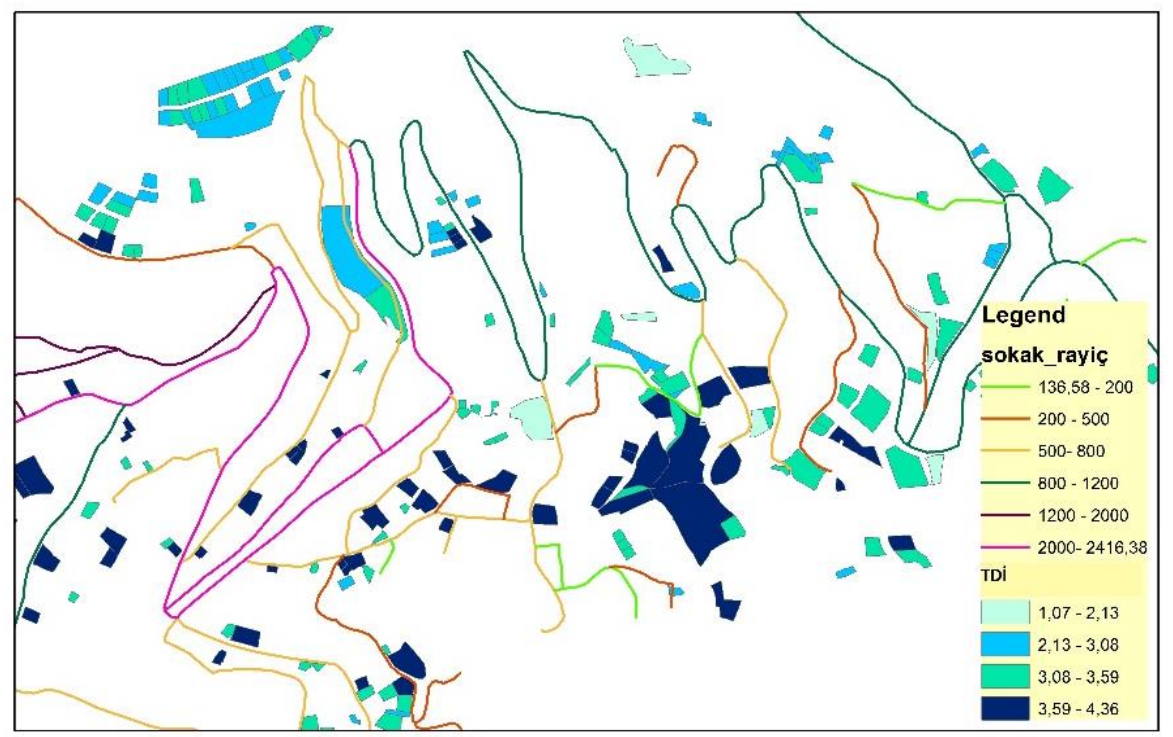

Şekil 3. Cadde/sokak emlak rayiç değerleri ile taşınmaz değer indeksleri

\section{SONUÇLAR ve ÖNERILER}

Bu çalıșmada, Artvin kent merkezinde arsa vasıflı taşınmaz malların değeri üzerinde etkili olan faktörler ve etki dereceleri uzman görüșleri doğrultusunda AHP yöntemi kullanılarak belirlenmiştir. 15 faktörün analiz edildiği bu çalışma sonucunda arsa vasıflı taşınmaz malların üzerinde en çok etkiye sahip 3 faktörün "Şehir merkezine yakınlık", "Sokak genişliği" ve "Toplam inşaat alanı" olduğu, en az etkiye sahip 3 faktörün ise "Hastaneye yakınlık", "İkokula yakınlık" ve "Parselin konumu" olduğu tespit edilmiştir. Faktörlerin ve ağırlıklarının belirlenmesinin ardından Artvin Merkezde (7 Mahalle ölçeğinde) tespit edilen 273 adet arsa vasıflı taşınmaz malın taşınmaz değer indeksi hesaplanmıștır. $\mathrm{Bu}$ bağlamda hesaplanan indekslerin 1.07 ile 4.36 aralığında değiştiği ve en yüksek değer indeksli parsellerin (65 arsa vasıflı taşınmaz mal) genellikle Çarşı Mahallesinde (merkezde) yer aldığı ve alanca \%90'ından daha fazla kullanılabilir alana sahip olduğu ve tamamına yakınının emsalinin yüksek olduğu tespit edilmiștir. Ayrıca hesaplanan taşınmaz değer indeksleri, 2015 yllında satışa konu olan ve tapudaki satış fiyatları temin edilen 47 arsa vasıflı taşınmaz mal bazında analiz edilmiştir. $\mathrm{Bu}$ kapsamda yapılan hesaplamalarda, tapudaki satış fiyatı ile tahmini fiyatlar arasında farklılıkların olduğu ve bu farklılıkların her iki yönde de mevcut olduğu belirlenmiştir. Şöyle ki bir yanda arsa vasiflı taşınmaz mallar gerçek değeri altında satılabilirken öte yanda gerçek ederinden daha büyük meblağlara da satılabilmektedir. $\mathrm{Bu}$ durum ise, üretilen modellerin doğrulanması noktasında kısıtlar oluşturmaktadır. Yine literatürde belirtildiği gibi bu çalışmada da piyasa değeri ile emlak vergisi değeri arasında büyük farkların olduğu, Belediyelerce belirlenen cadde/sokak rayiçlerinin düşük olduğu ve taşınmaz malın gerçek değerini yansıtmadığı, aynı cadde/ sokak üzerinde arsa vasıflı taşınmaz malların $\mathrm{m}^{2}$ fiyatı aynı olmasına rağmen parsellerin oldukça farklı değerlerde olduğu gözlenmiştir.

$\mathrm{Bu}$ bağlamda taşınmaz değer indekslerinin, taşınmazların sahip olduğu özellikler dikkate alınarak belirlenmiş olması, güvenilir, gerçekçi ve yeterli miktardaki bir veri setiyle istenilen zaman için taşınmazın piyasa değerine dönüştürülebilmesi imkanı oldukça önem taşımaktadır. Dolayısıyla taşınmaz malların konumsal, fiziksel, sosyoekonomik, ülke ve bölgesel politikalar, lokal koşullar gibi tüm özellikleri dikkate alınarak parsel tabanlı gerçek değerlerinin belirlenmesi, kent bazlı değer indeks haritalarının üretilmesi ve bu değerlere ihtiyaç duyan işlemlere (alım-satım, bankacılık, sigorta vb) servis edilmesi oldukça önemli ve 
elzemdir. Aynı zamanda ülke ekonomisi açısından da büyük öneme haizdir. Bu noktada özellikle son yıllarda hızla gelișen bilgi teknolojileri, bu sürecin üstesinden gelinmesini de mümkün kllacak niteliktedir. Bu bağlamda son zamanlarda gündeme gelen Taşınmaz Değerleme Sisteminin kurulması ve ilgili mevzuat oluşturma çalışmalarının başlatılması olumlu bir adım olmakla birlikte sürecin sağlıklı ve ivedi bir şekilde tamamlanabilmesi de oldukça önem taşımaktadır.

Öte yandan, bu çalışmanın Artvin kent merkezi örneğinde taşınmaz mal değerleme konusunda yapılan ilk çalışma olması nedeniyle, Artvin taşınmaz pazarının izlenmesi ve yönetimine önemli katkılar sunması beklenmektedir.

\section{TEŞEKKÜR}

$\mathrm{Bu}$ çalışma, Artvin Çoruh Üniversitesi Bilimsel Araştırma Koordinatörlügü tarafından desteklenen 2016.F40.02.03 numaralı projeden üretilmiştir.

\section{KAYNAKÇA}

Akıncı, H., Yavuz Özalp, A. ve Turgut, B. (2012). AHP Yöntemi ile Tarıma Uygun Alanların Belirlenmesi, IV. Uzaktan Algllama ve Coğrafi Bilgi Sistemleri Sempozyumu (UZAL-CBS 2012), 16-19 Ekim 2012, Zonguldak.

Akıncı, H., Yavuz Özalp, A. ve Temuçin Kılıçer, S. (2015). Landslide Susceptibility Assessment in Planned Areas Using Geographical İnformation Systems and AHP Method: The Case of Artvin, J Nat. Hazards and Environ, 1(1-2), 40-53.

Akış, B. (2013). İstatistiki Yöntemlerle Değer Belirleme ve Değer Haritası Üretimi-Selçuklu Örneği, Selçuk Üniversitesi, FBE, Yüksek Lisans Tezi, Konya.

Ayan, E. ve Erkin, H.C. (2014). Hedonic Modeling For a Growing Housing Market: Valuation of Apartments in Complexes, Int. J. Econ. Fin., 6(3), 188-199.

Bin, O. (2004). A Prediction Comparison of Housing Sales Prices By Parametric Versus SemiParametric Regressions, J. Hous. Econ., 13, 6884.

Bozkurt, Ö. (2016). Denizli'de Gayrimenkul Değerini Etkileyen Fiziksel Unsurların Tespitine Yönelik Bir Araştırma, Pamukkale Üniversitesi SBE İşletme Anabilim Dalı Muhasebe ve Finansman Bilim Dalı Tezsiz Yüksek Lisans Projesi, Denizli.

Çakır, P. ve Sesli, F.A. (2013). Arsa Vasıflı Taşınmazların Değerine Etki Eden Faktörlerin ve $\mathrm{Bu}$ Faktörlerin Önem Siralarının Belirlenmesi, Harita Teknolojileri Elektronik Dergisi, 5(3), 1-16.
Daşkıran, F.. (2015). Denizli Kentinde Konut Talebine Etki Eden Faktörlerin Hedonik Fiyatlandırma Model ile Tahmin Edilmesi, Uluslararası Sosyal Araştırmalar Dergisi, 8(37), 850-857.

Deveci, E. ve Yılmaz, İ. (2009). Coğrafi Bilgi Sistemleri Yardımıyla Taşınmaz Mal Değerlemesi: Afyonkarahisar İl Merkezi Örneği, Harita Teknolojileri Elektronik Dergisi, 1 (1), 33-47.

Döner, S. ve Alkan, R.M. (2011). CBS Destekli Taşınmaz Mal Değer Haritalarının Oluşturulması, TMMOB HKMO, 13. Türkiye Harita Bilimsel ve Teknik Kurultayı, 18-22 Nisan, Ankara.

Emek, M.L. ve Öztürk, S. (2015). Taşınmazların Satış Suretiyle Devrinde Piyasa Fiyatlarının Kullanılmamasının Kamu Gelirleri Üzerine Etkisi: Adıyaman İli Gölbaşı İlçesi Örneği, International Journal of Social Science, 39, 529539.

İlhan, A.T. (2017). Uygulamalı Arsa/Arazi Değerlemesi, Ankara Doğal Elektrik Üretim Ve Ticaret A.Ş. Genel Müdürlüğü Özelleștirme Hizmetleri Grup Başkanlığı.

Karaca, H. (2008). Taşınmaz Mal Değerlemesi Yöntemleri ve Karşılaştırılması, Yüksek Lisans Tezi, İTÜ FBE, İstanbul.

Karakayacı, Ö. ve Karakayacı, Z. (2012). Kentsel Saçaklanma Alanlarında Arsa/Arazi Değerini Belirlemeye Yönelik Yöntem Önerisi, The Journal of Academic Social Science Studies, 5(4), 107-120.

Kauko, T.J. (2002). Modelling The Locational Determinants of House Prices: Neural Network And Value Tree Approaches, PhD thesis, Utrecht, Utrecht University, Holland.

Kavas, E. (2009). Analitik Hiyerarşik Süreç Yöntemiyle İzmir İlinde Heyelan Duyarlılığının Coğrafi Bilgi Sistemleri Tabanlı İncelenmesi, TMMOB Coğrafi Bilgi Sistemleri Kongresi (CBS2009), 02-06 Kasım, İzmir.

Kırar, B. (2008). Taşınmazlarda Emlak Vergisine Esas Değer, Tapu Değeri Ve Piyasa Değeri Arasındaki Farklılıkların İncelenmesi: Beşiktaş Örneği. İstanbul Teknik Üniversitesi, FBE, Yüksek Lisans Tezi, İstanbul.

Öztürk, D. ve Batuk, F. (2010). Konumsal Karar Problemlerinde Analitik Hiyerarşi Yönteminin Kullanılması, Yıldız Teknik Üniversitesi Sigma Mühendislik ve Fen Bilimleri Dergisi, 28, 124137. 
Saaty, T.L. (1980). The Analytic Hierarchy Process: Planning, Priority Setting, Resource Allocation, McGraw-Hill Comp., New York.

Timur, S. (2009). Coğrafi Bilgi Sistemleri Destekli Taşınmaz Değer Haritalarının Oluşturulması: İstanbul İli, Şișli İlçesi Örneği. İstanbul Teknik Üniversitesi, FBE, Yüksek Lisans Tezi, İstanbul.

TKGM. (2019). Tapu ve Kadastro Genel Müdürlüğü, Parsel Sorgulama Uygulaması, https://parselsorgu.tkgm.gov.tr/, E.T. 10.03.2019.

TKMP. (2014). Tapu ve Kadastro Modernizasyon Projesi (TKMP) Gayrimenkul Değerleme Bileşeni, Pilot Uygulama Taslak Tamamlanma Raporu, Eylül 2014.

Toktaş, M. ve Erdoğan, S. (2012). Hazine Arazileri İçin CBS Destekli Değer Haritalarının Üretilmesi: Afyonkarahisar Örneği, Harita Teknolojileri Elektronik Dergisi,4(3), 23-38.

Türk, E. ve Erkan, G.H. (2018). Gömleğin Her Düğmesini Yanlıș İliklemek: Artvin-Yusufeli Zorunlu Yeniden Yerleștirme Sürecinin Eleștirel İncelemesi, Planlama, doi: 10.14744/Planlama.2018.36854, 28(2), 218235.

Türkay, İ. (2015). Gayrimenkul Alım ve Satımının Vergisel Boyutlarl, https://vergialgi.net/makaleler/gayrimenkulalim-ve-satiminin-vergisel-boyutlari/,

E.T. 04.10.2018

Utkucu, T. (2007). Gayrimenkul Değerlemesinin Önemi ve Gayrimenkul Değerini Oluşturan Unsurlar, Vergi Dünyası Dergisi, 305, 1.

Yahşi, E. (2007). Konut Değerlemesi ve Konut Değerini Etkileyen Faktörlerin Regresyon Analizi ile İncelenmesi. İstanbul Teknik Üniversitesi, FBE, Yüksek Lisans Tezi, İstanbul.

Yalpır, Ş., Ünel, F.B. ve Kahramanlı, H. (2013). Comparison of Values in Real Estate Valuation Example of Konya, Recent Advances in Geodesy and Geomatics Engineering, www.wseas.us/elibrary/.../GENG-03.pdf, E.T. 14.04.2016.

Yalpır, Ş. (2014). Forecasting Residential Real Estate Values with AHP Method and Integrated GIS, In Conference Proceed of People, Buildings and Environment 2014, an international scientific conference, Kroměřŕž, Czech Republic, 694-706, ISSN: 1805-6784.

Yalpır, Ş. ve Bünyan Ünel, F. (2016). Türkiye'de ve Uluslararası Çalışmalarda Arsa Değerlemede Kullanılan Kriterlerin İrdelenmesi ve Faktör Analizi ile Azaltımı, AKÜ Fen ve Mühendislik
Bilimleri Dergisi, 16 (2016) 025502, 303-322, doi: $10.5578 / \mathrm{fmbd} .28134$.

Yavuz Özalp, A., Akıncı, H., Temuçin, S. (2013). Artvin İli Arazisinin Topoğrafik ve Bazı Fiziksel Özelliklerinin Tespiti ve Bu Özelliklerin Arazi Örtüsü İle İlișkisinin İncelenmesi, Artvin Çoruh Üniversitesi Orman Fakültesi Dergisi, 14(2), 292-309, 2013.

Yavuz Özalp, A. ve Akıncı, H., (2017a), Determining Parameters Affecting Residential Real Estate Value and Their Significance Level Using AHP Method: The Case Study of Artvin, Int.Symposium on GIS Applications in Geography Geosciences,18-21 Ekim, Çanakkale.

Yavuz Özalp, A. ve Akıncı, H. (2017b). The Use of Hedonic Pricing Method to Determine The Parameters Affecting Residential Real Estate Prices, Arabian Journal of Geosciences, 10, 535, https://doi.org/10.1007/s12517-017-3331-3.

Yetkin, G. (2009). Toplu Konut Uygulamalarındaki Fiziksel Mekan Özelliklerinin İrdelenmesi "Konya Örneği". Selçuk Üniversitesi, FBE, Yüksek Lisans Tezi, Konya.

Yılmaz, A. ve Demir, H. (2011). Çok Ölçütlü Karar Destek Sistemleri İle Taşınmaz Değerleme ve Oran Çalışması, TMMOB HKMO 13. Türkiye Harita Bilimsel ve Teknik Kurultayı, 18-22 Nisan, Ankara.

Yomralığlu, T. (1995). Tașınmaz Malların Değerlendirilmesi, Ders Notları, KTÜ, Trabzon.

Yusof, A. ve Ismail, S. (2012). Multiple Regressions in Analysing House Price Variations, Communications of The IBIMA, doi: 10.5171/2012.383101, http://www.ibimapublishing.com/journals/CI BIMA/cibima.html. 